\title{
REVIEW
}

\section{Review on drivers, trends and emerging issues of the food wastage in China}

\author{
Lin MA $(\bowtie)^{1}$, Wei QIN ${ }^{2}$, Tara GARNETT ${ }^{3}$, Fusuo ZHANG \\ 1 Key Laboratory of Agricultural Water Resources, Center for Agricultural Resources Research, Institute of Genetic and Developmental \\ Biology, Chinese Academy of Sciences, Shijiazhuang 050021, China \\ 2 Department of Soil Quality, Wageningen University and Research Centre, Wageningen 6700, the Netherlands \\ 3 Food Climate Research Network, Environmental Change Institute, University of Oxford, Oxford OX1 3QY, UK \\ 4 Department of Plant Nutrition, Key Laboratory of Plant-Soil Interactions of Ministry of Education, China Agricultural University, \\ Beijing 100193, China
}

\begin{abstract}
China has successfully achieved food selfsufficiency over the past 50 years, however, with large inputs and losses. To meet the challenge of feeding a growing population with limited resources, many studies have explored options for improving productivity and efficiency of the food production. However, there have been few studies into the potential of reducing food loss along the whole food production-consumption chain. Here we review the literature on food waste in China. We briefly analyze (1) the drivers that influence levels of food waste in the food chain, (2) examine trends in the volumes and types of food wasted at different stages in the food chain, (3) assess the environmental and resource consequences of food waste in the food chain, and (4) evaluate the policy and stakeholder responses to the emerging challenges. It is concluded that reducing food loss and meeting food security in China requires a coherent institutional structure that promotes the synergistic outcomes of research, policy and education. Suggested key actions include (1) improving machinery and facility for sowing, harvesting, transportation and storage, which can reduce food loss by up to $50 \%$, and (2) improving food waste recycling management, based on coupled food production and consumption systems.
\end{abstract}

Keywords food security, food chain, food wastes and losses, environmental impacts

Received March 7, 2015; accepted July 3, 2015

Correspondence: malin1979@sjziam.ac.cn

\section{Introduction}

Globally, food wastage accounts for $30 \%-35 \%$ of the total food production ${ }^{[1]}$. Meanwhile, there are about 805 million people still in hunger or under nourished ${ }^{[2]}$. Hence, sustainable development has to concurrently address increasing food supply and reducing large food wastes and losses. Sustainable agriculture and food supply is a crucial global challenge for increasing food productivity, resource use efficiency and environmental quality, and reducing food waste and poverty ${ }^{[3,4]}$. The majority of global challenge is in a few leverage points/countries, driven by a few commodities ${ }^{[5]}$, such as China, the rapid increases of agriculture have depended on significant increases in resources inputs including agricultural land, water, and nutrients, and these in turn have caused serious environmental damage through nutrient losses to rivers and aquifers, and increases in greenhouse gases emissions (GHG) from the food production and consumption chain $^{[6]}$.

Food security is of top priority on China's political agenda. Although food production is mostly constrained by the environment (e.g., climate and soil) and agricultural inputs (e.g., water and nutrients) ${ }^{[7-13]}$, improper policymaking may also lead to failure in food production, and thereby food security. The most recent famine in China took place in 1960s, since then China has adjusted its policy, including agricultural policy, and has successfully achieved food self-sufficiency. Today, despite of large heterogeneity within the society, China has changed from insufficient to sufficient food supply ${ }^{[14]}$. However, research and policy development continues to address food production but tends to neglect food waste and losses ${ }^{[15]}$.

In China, most of research and policy focus on 
improving food productivity, ignoring food waste management and environmental impacts. There are only a small number of major national science and technology projects on food waste management in China. Some studies address the comprehensive food waste utilization technology, such as reuse of edible oil wastes and food waste purification and recycling ${ }^{[16]}$. However, the integrated research on food chain (farmer - food processing - transport - retailerconsumer) wastage is almost non-existent ${ }^{[17]}$.

Here, we review the literature of food waste in China. First, we give a brief analysis of the drivers that influence the level of food waste in food chain. Next, we examine trends in the volume and type of food waste at different stages in the food chain. Then, we assess the environmental and resource consequences of food waste and losses in the food chain. Finally, we evaluate the policy and stakeholder responses to the emerging issues and challenges.

\section{Drivers of food waste}

The main driving force behind food wastage is economic growth and increased income and purchasing power. China's economy, in terms of GDP, is ranked the second in the world and has the highest growth rate ${ }^{[18]}$. In 2009, China's GDP was about 5 trillion USD, which was about 100 times that in 1960s (Appendix A, Fig. S1). During the period 1978 to 2010, mean income increased from 343 to 19109 CNY per capita per year for urban people and from 134 to 5919 CNY per capita per year (Appendix B, Table $\mathrm{S} 1$ ). Along with this rapid economic growth and increased income also lead to improved overall living, including food consumption. For example, daily food protein consumption increased from 25 to $72 \mathrm{~g}$ per capita per day, and percentage of animal protein intake increased from 9\% to 35\% from 1961 to 2007 (Appendix A, Fig. S2). Accordingly, plant derived food consumption gradually decreased (Appendix A, Fig. S3). As a result, the number of under-nourished people declined rapidly, while excessive weight and obesity increased in both children and adults $^{[19,20]}$.

The second driving force behind food wastage is development of agriculture, which now provides enough food. From 1961 to 2009, cereal production in China increased from about 100 to $500 \mathrm{Mt}$, greatly reducing food shortages. Meanwhile, crop yield increased from 1.3 to $5.4 \mathrm{t} \cdot \mathrm{hm}^{-2[14,21]}$. At the same time, livestock production also rapidly developed. For example, since 1978 the number of pigs, sheep, poultry, and beef and dairy cattle increased by 3.0, 9.2, 5.7, 18.1 and 25.5 times, respectively (Appendix A, Fig. S4). Today, China ranks first in annual production of meat in the world. There has been a shift from small household animal production to large and industrialized production. Currently more than $50 \%$ of animals are raised in confined feeding operations ${ }^{[22]}$.
The third driving force behind food wastage is the policies on agriculture and food waste. China's government, because of the large population, considers grain production as crucial for of the country. However, there have been many changes in policymaking. For example, cropland decreased annually $0.6 \%$ from 1996 to 2003 through the conversion of some marginal and hilly cultivated land into timber production ${ }^{[23]}$, and this coincided with a decrease in grain production. To deal with declining grain production, the government started to encourage grain production through a series of policies such as subsidizing grain production, providing elite cultivars to farmers, purchasing agricultural machinery, and subsidies on agricultural inputs. The subsidy payments are made on the basis of the consumption of inputs. For example, Comprehensive Subsidy on Agricultural Inputs was established in 2006, the budget of this program has increased from 12 billion $\mathrm{CNY}$ in 2006 to 71.6 billion CNY in $2010^{[24]}$. As a result, since 2003 when grain production area was at lowest, the area of grain production increased by $11 \%$ to $109.9 \mathrm{Mhm}^{2}$, Also by 2011, the area of plastic film coverage reached about $20 \mathrm{Mhm}^{2}$, and the amount of plastic film used reached $1.25 \mathrm{Mt}$, which increased grain yield per hectare by up to $60 \%[25]$. Farmers had become greatly motivated to produce grain $^{[26]}$. Besides grain production, the government also started to reform the national grain distribution, storage, processing and consumption systems. In 2009, a project to reduce grain losses after harvest was initiated by construction of better granaries to decrease the grain losses during storage ${ }^{[27]}$. In 2010 , a notice about strengthening food saving and eliminating food waste was released by the government ${ }^{[28]}$, which emphasized four aspects: (1) increasing awareness of food saving, (2) listing strategies of food saving, (3) educating and disseminating food saving to the public, and (4) monitoring and evaluating food waste behavior.

\section{Trends in food wastes and losses}

\subsection{Estimating food waste in the food production chain}

Concomitant with changes mentioned above, there have been changes in the food chain. Jenny et al. reported that the causes of food losses and waste in low-income countries are mainly connected to financial, managerial and technical limitations in harvesting techniques, storage and cooling facilities in difficult climatic conditions, infrastructure, packaging and marketing systems ${ }^{[1]}$.

$\mathrm{Xu}$ reported that total food grain losses in China's food chain was 58.9 Mt in 2004, which accounted for more than $12 \%$ of main grain products ${ }^{[29]}$. The storage sector was by far the largest source of food grain losses (41\%, Fig. 1). Harvest was the second largest contributor (33\%). The contribution of sowing, transportation, processing, food 


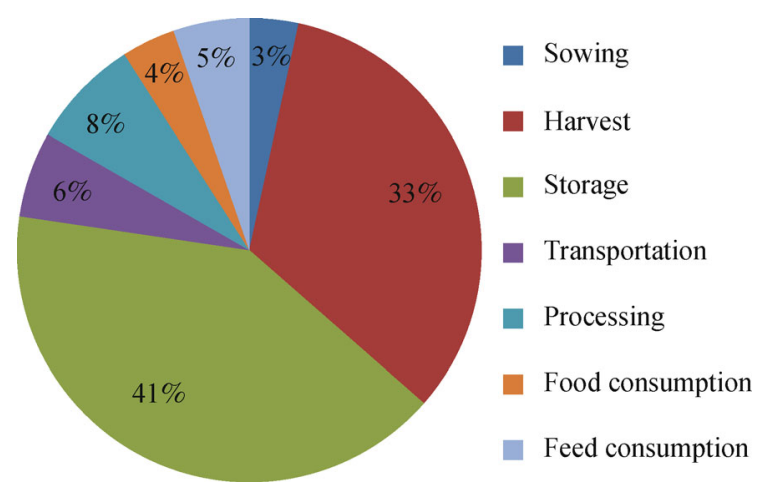

Fig. 1 Relative contribution (\%) of the sowing, harvest, storage, transportation, processing, and food consumption and feed consumption to the total grain food losses in China at national level in 2004

consumption and feed consumption was estimated at $3 \%$, $6 \%, 8 \%, 4 \%$, and $5 \%$ (Fig. 1). However, there have been no equivalent reports for losses in livestock, fruit and vegetable production.

During sowing, seed wastes were $2 \mathrm{Mt}$ caused by excessive seeding rates (Fig. 1). In China, establishment rates are low, because most of small famers sow manually or use small hand-operated seeders. Therefore, famers had to enlarge to shift from hand sowing to using seeding machinery to give better control over seeding depth and rate, such that less seed would be wasted.

During harvest, the grain losses were about $19.4 \mathrm{Mt}$, accounting for $5 \%$ of total production (Fig. 1). In China, the rate of machine harvesting is about $82 \%, 15 \%$, and $2 \%$ for wheat, rice, and maize, respectively. The grain waste during hand-harvesting is more than when using machinery. Also, there was lack of the drying equipment, therefore, during storage some of grain germinates and becomes moldy.

During grain storage, the grain losses were about $24 \mathrm{Mt}$, because $70 \%$ of storage is on small farms. Most grain produced by small farmers is consumed by their own families and there is a lack of appropriate grain storage facilities. However, during the past several decades, China has made great progress in grain storage research, which has greatly improved and promoted grain storage techniques and facilities. Especially in the 1990s, modern grain storage depots were constructed, in which four new technologies of grain inspection automation, machinery aeration, grain cooling and phosphine recirculating fumigation were facilitated. The government has invested in building advanced storage facilities, and most elevators have been equipped with power ventilation appliances, computer controlled temperature measuring systems and fumigation recycling devices ${ }^{[30,31]}$.

During grain transportation, the grain losses were about 3.5 Mt (Fig. 1). Every year, a large amount of grain is delivered from producing areas to the major markets. A modern logistics system with seamless transportation links between loading, unloading, transporting and storage are needed to enhance efficiency of grain distribution and lower the food waste.

During grain processing, the grain losses were about 4.5 Mt (Fig. 1). Since the liberalization of the grain market in 1990s, many large scale processing enterprises have established a network of branches replacing independent grain milling operations.

\subsection{Food waste in food consumption}

In food and feed consumption, grain losses were 2.2 and 3.1 Mt, respectively ${ }^{[29]}$. Ma reported that food consumption in the restaurants have increased since 1990s, especially in urban areas ${ }^{[32]}$. At the same time, rapid development in animal production increased the feed demand, especially for maize and soybean.

Figure S5 shows food waste at the household level in China in 1982, 1992 and 2002. Data for the fraction of food waste in the household are based on the estimates of Wei et al. ${ }^{[33]}$. Between 1982 and 2002, the total amount of food waste in the urban areas increased nearly 4 times, but remained unchanged rural areas. The changes of the total amount of food waste (including unavoidable wastes, e.g., banana peel and bones in meat, and avoidable wastes, e.g., leftovers in households and restaurants) due to increasing population and urbanization (from $21 \%$ to $40 \%$ ) and the changes in food waste per person (Appendix A, Fig. S6). Plant and animal food waste per person increased in urban areas between 1982 and 2002, while only animal food waste increase in rural areas during the same period. The per capita urban plant food waste, urban animal food waste, rural plant food waste, rural animal food waste increased $62 \%, 240 \%$, and $142 \%$, whereas rural plant food waste decreased by $13 \%$ (Appendix A, Fig. S6).

There are three reasons for the increasing per capita food waste. The first reason is the growing of food consumption in both urban and rural area. The second reason is more animal-derived food consumption, which has more unavoidable wastes, e.g., bones and animal organs. The third is that the per capita food waste went up between 1982 and 2002 faster than the increase in food consumption.

\subsection{Food waste in the catering industry}

With the exploding urbanization and the increase pac of modern life, more and more people consume food in restaurants in urban China, rather than at home, which drives the booming of catering industry ${ }^{[34-36]}$. Cheng et al. estimated that food waste at provincial capitals was roughly $6 \mathrm{Mt}$ in $2008^{[16]}$. Based on city size, there are five levels of food wastage have been established, first level cities (Beijing and Shanghai) produce 1000-1600 t of food waste per day, second level cities (such as Changsha, 
Nanjing) produce 600-1000 t, third level cities (e.g., Fuzhou and Taiyuan, etc) produce $360-600 \mathrm{t}$, fourth level cities (e.g., Shenyang) produce 150-360 t, and fifth level cities produce less than $100 \mathrm{t}$. This estimation of food wastage in catering industries has been reported by the media. Food wasted per capita based on the total amount of food waste and population, however, is a lack of research on relationship between city scale, economic development and incomes and food waste per capita. In general, the differences of food waste between cities are related to city size and population, economic development and number of restaurants. Based on data of Chinese Academy of Agricultural Sciences, protein and fat contained in food wasted in catering reached 8 and $3 \mathrm{Mt}$ per year, respectively, which is equivalent to the amount of food consumed by 200 million people per year ${ }^{[16]}$.

\subsection{Municipal organic waste}

Municipal organic waste (MOW) generated from daily life usually includes residual, institutional, commercial, street cleaning and non-process waste from industries ${ }^{[37]}$. The data of MOW production, which means the amount of collected and transported municipal organic waste by waste disposal plant per year, was cited from China Statistical Yearbook on Environment. The amount of transported MOW increased yearly with the mean rate of $6.8 \%$ in China. The total amount of MOW collected and transported was $148 \mathrm{Mt}$ in 2006 , of which $91 \%$ was landfilled, 6.4\% was incinerated, and $2.2 \%$ was composted. The overall MOW treatment rate in China was approximately $62 \%$ in 2007 . In 2007 , there were 460 facilities, including 366 landfill sites, 17 composing plants, and 66 incineration plants ${ }^{[37]}$.

The high ratio of organic waste in China is partly attributable to the diet, e.g., more fresh vegetables and fruit than before, and preferences for food that is unprocessed and unpackaged. In this sense, kitchen waste will also continue to occupy a high ratio of the waste in China. Therefore, there is great potential to collect and recycle food waste by improving municipal organic waste and waste water systems.

Moreover, resources in food production are expended in vain because of food waste and MOW caused by food waste aggravates environmental burden of the city and increases the cost of garbage disposal. In spite of the increase in safe disposal capacity (including landfilling, incineration, composting, and recycling), safe disposal rates in China have been below 55\% since 2002, and the remainder of the waste was uncollected ${ }^{[37]}$. These stable rates, together with the growth in total MOW generation, indicate that the amount of MOW without safe disposal has also increased, thus increasing the impact on the environment ${ }^{[38,39]}$.

In China, bio-waste in MOW is not sorted before disposal, typically in landfill or incineration plants, so most biogas plants are based on the digestion of animal manure and are built in the countryside using low efficiency and locally developed technology. Waste separation and collection are being developed in some big cities such as Beijing, Shanghai and Shenzhen to enable the conversion of bio-waste into biogas containing methane and the separation of solid materials from anaerobic digestion processes for use as fertilizers. Anaerobic digestion is suggested to be a promising treatment for the organic waste in China ${ }^{[40]}$.

\section{Food waste and its impacts}

Ma et al. developed a food chain model (NUFER-Nutrient flow in the food chain, environment, resource) that calculates the flows, and use efficiencies and emissions of $\mathrm{N}$ and $\mathrm{P}$ in the food chain of 31 regions and China on an annual basis ${ }^{[41]}$. The results show that for the delivery of a representative Chinese diet with $1 \mathrm{~kg}$ of protein $\mathrm{N}$ to households, the crop and animal production and food processing compartments used on average $11 \mathrm{~kg}$ of $\mathrm{N}(\mathrm{N}$ cost of food) and wasted $10 \mathrm{~kg}$ in 2005. Similarly, for the delivery of food to households with $1 \mathrm{~kg}$ of $\mathrm{P}$, the crop and animal production and food processing sectors used $13 \mathrm{~kg}$ of P (P cost of food), and wasted $12 \mathrm{~kg}$ P (Fig. 2). Indeed, the $\mathrm{N}$ and $\mathrm{P}$ economy of the food chain may be perceived as a pyramid; many $\mathrm{N}$ and $\mathrm{P}$ atoms have to support the few that are consumed at the top of the chain ${ }^{[42]}$.

For comparison, the estimated world average $\mathrm{N}$ cost of food cost is about 6, while that in USA was 7, in Germany 4 and in Norway 5. Similarly, the world average P cost of food was 9, while that was 6 for USA and the Netherlands ${ }^{[43]}$. These differences are likely to emanate from differences in human diets and food production systems, but also from differences in nutrient use efficiency in crop and animal production, and from differences in the recycling of nutrients in food residues and food wastes. However, the trend is clear, although the Chinese diet is still relatively low in animal protein compared to the diets in northern America and Europe, $\mathrm{N}$ and $\mathrm{P}$ cost of food in the whole food chain are high in China.

Most of $\mathrm{N}$ waste is lost in the atmosphere or water, or is accumulating in the soil. The total mean $\mathrm{N}$ loss via ammonia $\left(\mathrm{NH}_{3}\right)$ emissions was $117 \mathrm{~kg} \cdot \mathrm{hm}^{-2}$ in China in 2005. Losses via nitrous oxide $\left(\mathrm{N}_{2} \mathrm{O}\right)$ emissions and $\mathrm{N}$ leaching (including runoff, erosion and direct discharges) were 4 and $116 \mathrm{~kg} \cdot \mathrm{hm}^{-2}$, respectively. Total P losses via leaching, runoff, erosion and direct discharges were $21 \mathrm{~kg} \cdot \mathrm{hm}^{-2}$ in 2005 . Losses of $\mathrm{N}$ and P to surface waters increased more than losses to air and groundwater between 1980 and $2005^{[41]}$.

Wheat, rice and maize are the main staple grain crops grown in China. In 2000s, these crops accounted for about $50 \%$ of total planted area and more than $80 \%$ of total grain production. Practically all wheat and rice grown in China 

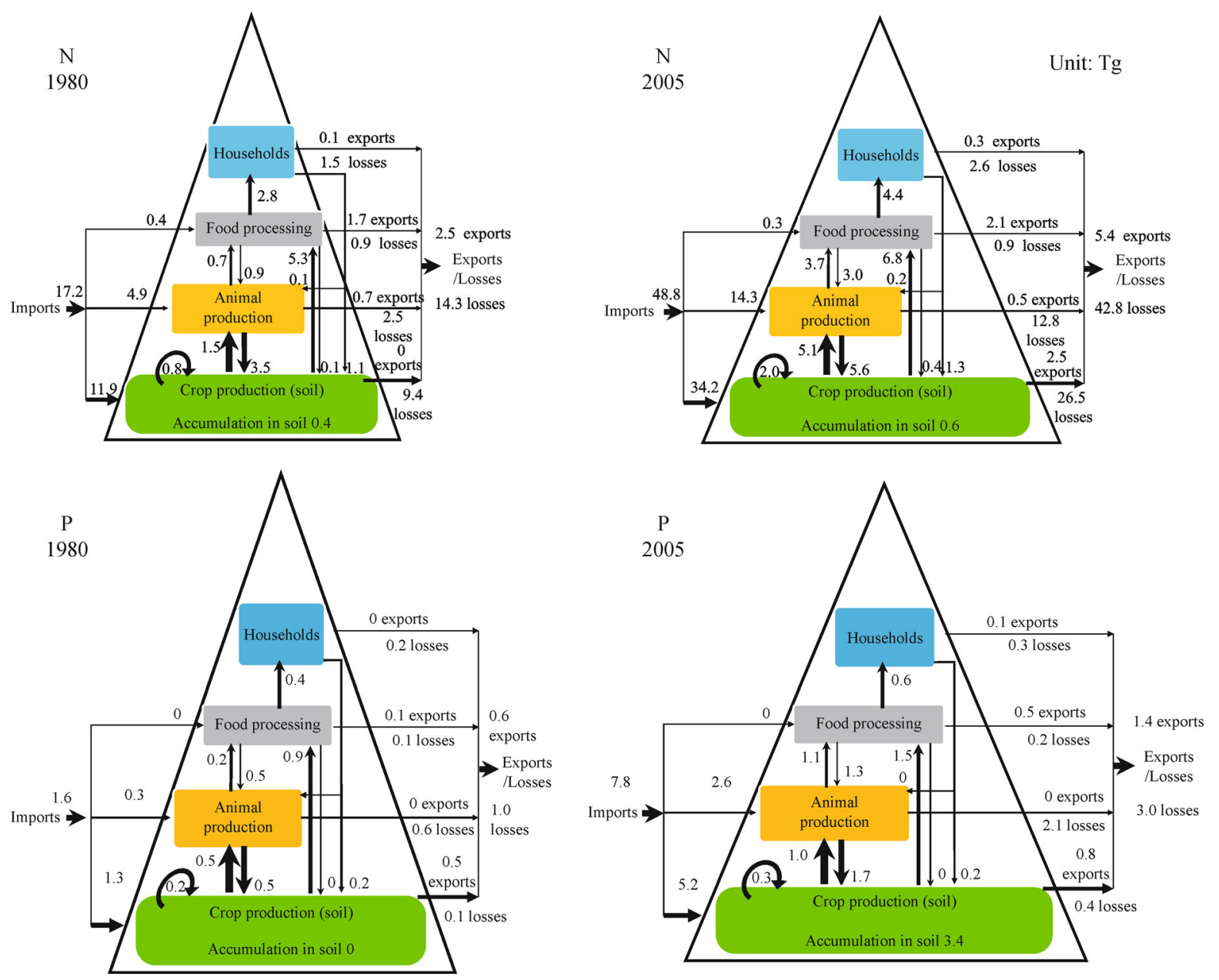

Fig. 2 The flows of $\mathrm{N}$ and $\mathrm{P}$ in the food pyramid in China at national level in 1980 and 2005 (Unit: $\mathrm{Tg}=10^{9} \mathrm{~g}$ )

are processed for direct consumption by humans, in contrast, maize is mainly use for animal feed. Ma et al. used materials flows analysis to analysis wheat, rice and maize flows from crop harvest, through food processing and distribution to consumption, using nitrogen $(\mathrm{N})$ as an uniformed unit. The results indicated that $\mathrm{N}$ losses in 2004 in China via grain harvest, straw (burning and other losses) and food processing were 68,300 , and $61 \mathrm{kt}$ for wheat. 124,617 , and $64 \mathrm{kt}$ for rice, 123,585 , and $50 \mathrm{kt}$ for maize (Fig. 3). $\mathrm{N}$ losses from harvest to consumption (main gain products and straw) were $16 \%, 21 \%$, and $19 \%$ for wheat, rice, and maize, respectively ${ }^{[4]}$ (Fig. 3).

There were significant regional differences in China. Losses of $\mathrm{N}$ and $\mathrm{P}$ from agriculture to atmosphere and water bodies increased in most regions, especially in the east and south of the country. Highest losses were estimated for the Beijing and Tianjin metropolitan regions (North China), Pearl River Delta (South China) and Yangzi River Delta (East China) ${ }^{[41]}$. Clearly, regional variations are related to (1) density of population and food demand, (2) the dominant farming system (traditional mixed smallholder versus the new landless confined animal feeding operations), and (3) the dominant animal species.

For food flows in households, Wei et al. using $\mathrm{N}$ as an example, analyzed the changes of $\mathrm{N}$ flows in household in urban and rural China from 1982 to 2002 . The $\mathrm{N}$ losses from cooking (food protein denaturation during the cooking) increased from 57 to $162 \mathrm{kt}$ in urban areas and from 189 to $205 \mathrm{kt}$ in rural areas between 1982 and 2002 (Appendix A, Fig. S7). This increase was driven by population growth and urbanization, and also more consumption of N-rich foods, such as meat and dairy, and changes of food processing and cooking style from rough processing to selective cooking. The $\mathrm{N}$ in the food waste increased from 50 to $128 \mathrm{kt}$ in urban, however, that decreased slightly from 182 to $174 \mathrm{kt}$ in rural areas between 1982 and 2002 (Appendix A, Fig. S7). There are three pathways: consumed, losses from cooking and food waste. In China, food wastes from household are processed by feeding animals, disposal in landfill, burning and composting. In urban areas, and landfill are the two main pathways of food waste. However, in rural areas, feeding animals, and composting are the main pathways ${ }^{[33]}$.

SAIN reported that in China for 2007 the total green- 

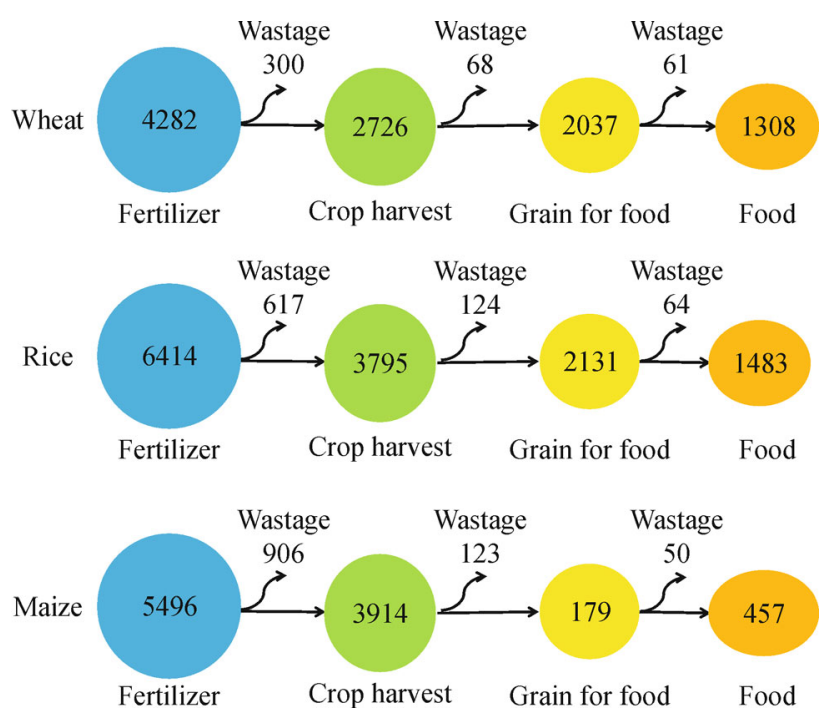

Fig. 3 Current status of nitrogen flow in wheat, rice, and maize production and utilization in China in 2004 (Unit: kt)

house gas (GHG) emissions connected with food production were about $1078-1312 \mathrm{Mt} \mathrm{CO}_{2}$ equivalent, which accounted for $15 \%-18 \%$ of total GHG emissions ${ }^{[45]}$. If we assumed that around $30 \%$ of food was wasted in China (the rate in industrialized Asia ${ }^{[1,46]}$, that means $5 \%-6 \%$ of total GHG emissions are caused by food waste in China. Lin et al. also reported that food consumption (accounting for $15 \%$ of GHGs) was the third largest contributor of GHG gas emission in the urban residential consumption in China $^{[47]}$.

Another study of Liu et al. indicated that in China the loss rate for food grains in the entire supply chain is $19 \%$. The total water footprint (WF) related to food losses and waste in China in 2010 was estimated to be 135 billion $\mathrm{m}^{3}$, equivalent to the WF of Canada. Such losses also imply that $26 \mathrm{Mhm}^{2}$ of land were used in vain, equivalent to the total arable land of Mexico ${ }^{[48]}$.

\section{Policies and other stakeholder responses}

The food waste management system in China is highly fragmented and still in development. There are many different actors, with different objectives and policy instruments. Governmental organizations still have a dominant influence, but following the policy reforms toward a more market-driven production in the 1980s, industries and small businesses, and also universities and research institutes have become more important.

Increasing agricultural production and food security have been the primary objectives of Central Government and the Ministry of Agriculture. These central objectives have been translated in targets and production incentives (subsidies) at regional levels. Regional governors though strongly focus on industrial development and employment, also because the resulting economic growth is very helpful for their own promotion to higher positions. So far, regional governments pay little attention to food security and environmental protection. However, there are no actors who took food waste management as their objective. Detailed explanations of this follow.

The Ministry of Agriculture and the associated (regional) Bureaus of Agriculture are in charge of food security, also at regional levels. They have a strong influence on farmers' activities, through providing direct advice and subsidies to farmers and indirectly through subsidies on non-factor inputs such as fertilizers and irrigation water. However, they are not responsible for improving crop harvest and implementation of targets, thresholds and/or guidelines related to sound crop harvest management at a farm level. More subsidy for mechanical harvesting should be provided by government, in the meanwhile, drying equipment for use before grain storage is necessary to improve crop harvest management. These two issues should be the responsibility of state administration of grain.

Environmental protection is the primary objective of the Ministry of Environmental Protection and the associated (regional) Bureaus of Environment Protection. However, their influence in farmer, food industry, food transportation and retailer, consumer is limited, because they have no authority as yet any influence on their activities. Moreover, the Ministry of Environmental Protection did not consider food waste as main environment pollution source and their primary emission reduction objective.

Also, universities, research institutes and non-government organizations (NGOs) have become more important in technology development. Some have become actively involved in improving food processing technology for economic objectives and meeting consumer requirements. 
However, they are not responsible for decreasing waste.

In summary, food waste management is fragmented and evolving. There are many actors and barriers, and as yet no food waste management strategy and policy.

\section{Concluding remarks}

China is in transition from an agrarian society to an industrial society ${ }^{[49]}$. This transition has huge implications for the food system, including food production and food waste, and for the sustainable development of rural and urban areas ${ }^{[6]}$. The productivity and efficiency in current crop and animal production are low, compared with industrialized countries. In the near future, it is likely that small-holder crop and animal production will disappear and food production will be taken over by specialized firms. Similarly, food storage, processing and transportation will be done increasingly by collective and industrial firms. It is likely that these specialized firms, and cooperative and industrial chains will be more able to develop the knowledge base and to invest in technology for sound food waste management than is happening currently. These changes may decrease the food waste in production to harvest and processing to transport parts of the food chain.

These changes will also influence food consumption, especially increasing food consumption in restaurants in urban areas due to increased income. Hence, a major challenge will be to educate consumers. From food consumption perspective, a greener diet (i.e., a diet with less meat consumption), would reduce chronic disease, improve the quality of soil, water and atmosphere ${ }^{[50]}$. Achieving a more plant-based diet is a huge challenge, especially for Chinese people, most of whom have only relatively recently emerged from hunger and poverty. Nevertheless the awareness of the need to reduce food waste and luxurious food consumption should be encouraged.

Food waste management should be jointly designed, implemented, monitored, and evaluated. Integrated food waste management may be a useful approach, although it is not easy. Fig. 4 lists the main actors of food waste management, a speculative process of food waste management and includes the proposed instruments. A series of future activities can be defined for food waste management in China as follows.

(1) To define objectives of food waste management by government agencies and scientists, considering food saving, resource use and environment protection.

(2) To analysis food waste in the whole food supply chain. Communicating this message to all stakeholders (the public, policymakers and governments) through uniform tools and approaches. The actors in this step are scientists and NGOs.

(3) To make food waste management plans for farmers and consumers, improve technology for food production and processing industries. The actors in this step are government agencies, scientists and NGOs. This step results in policies (such as food consumption tax, implement environmental tax and law to control food waste during consumption), improved technology, improved agricultural extension services, educated farmers and citizens' food saving and environmental awareness.

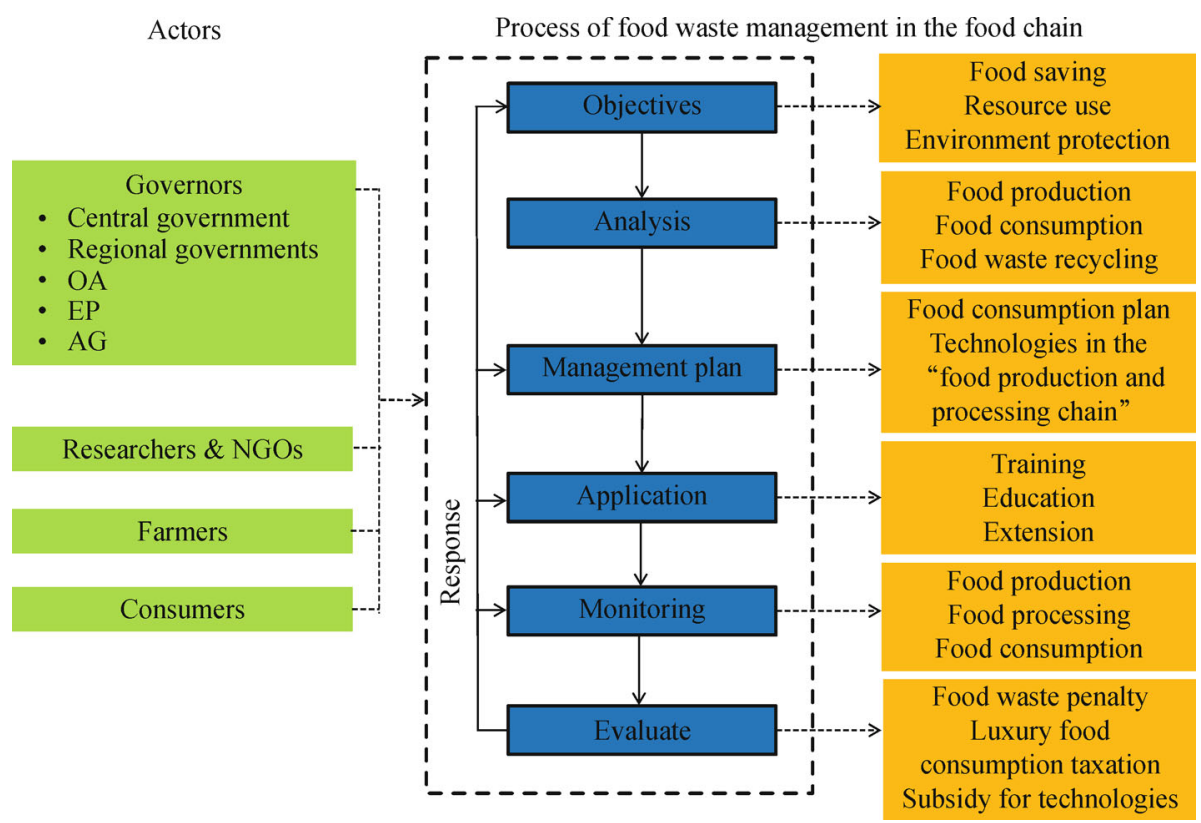

Fig. 4 The speculative framework of food waste management in the food chain in China. MOA, Ministry of Agriculture; MEP, Ministry of Environmental Protection; SAG, State Administration of Grain; NGOs, non-governmental organizations. 
(4) To apply the food waste management plans in practice, taking into account management guidelines and recommendations by education, training and extension. The main actors are farmers and the food processing industry. However, technology, education and extension subsidy should be provided by government agencies. Moreover, consumers are also the actors of food waste management to optimize food consumption and reduce and recycle waste.

(5) To monitor indicators and evaluate the achievements relative to objectives. Sometimes, the objectives will need to be modified in response to assessment results, which is the evaluation response to steps 1 to 4 . Food waste penalties and consumption taxation should be implemented. Subsidy for improved technology for deceasing food waste in the production - harvest - processing stages of the food chain would support the implementation of food waste management plans.

This review highlights that a transition is also needed for food waste management chain to ensure food security, to achieve the triple challenges of saving food, increasing resource use efficiency and ensuring an environmentally sound food production and consumption chain.

Acknowledgements Financial support for this work was provided by the Hundred Talent Program of the Chinese Academy of Sciences and Food Climate Research Network. We thank Dr. Andreas Wilkes, Dr. Liwei Gao, and Prof. Wenqi Ma for their valuable comments.

Supplementary materials The online version of this article at http://dx. doi.org/10.15302/J-FASE-2015066 contains supplementary materials (Appendix A and B).

Compliance with ethics guidelines Lin Ma, Wei Qin, Tara Garnett, and Fusuo Zhang declare that they have no conflict of interest or financial conflicts to disclose.

This article does not contain any studies with human or animal subjects performed by any of the authors.

\section{References}

1. Jenny G, Christel C. Global food losses and food waste. Rome: Food and Agriculture Organization of the United Nations, 2011

2. FAO. The State of Food Insecurity in the World. Rome: Food and Agriculture Organization of the United Nations, 2014

3. Thematic Group on Sustainable Agriculture and Food Systems of the Sustainable Development Solutions Network. Solutions for Sustainable Agriculture and Food Systems. New York: SDSN of United Nations, 2013

4. Garnett T, Appleby M C, Balmford A, Bateman I J, Benton T G, Bloomer P, Burlingame B, Dawkins M, Dolan L, Fraser D, Herrero M, Hoffmann I, Smith P, Thornton P K, Toulmin C, Vermeulen S J, Godfray H C. Sustainable intensification in agriculture: premises and policies. Science, 2013, 341(6141): 33-34

5. West P C, Gerber J S, Engstrom P M, Mueller N D, Brauman K A, Carlson K M, Cassidy E S, Johnston M, MacDonald G K, Ray D K, Siebert S. Leverage points for improving global food security and the environment. Science, 2014, 345(6194): 325-328

6. Tara G, Andreas W. Appetite for change: social, economic and environmental transformations in China's food system. Oxford: Food Climate Research Network, 2014

7. Cui S, Shi Y, Groffman P M, Schlesinger W H, Zhu Y G. Centennial-scale analysis of the creation and fate of reactive nitrogen in China (1910-2010). Proceedings of the National Academy of Sciences of the United States of America, 2013, 110 (6): 2052-2057

8. Piao S, Fang J, Ciais P, Peylin P, Huang Y, Sitch S, Wang T. The carbon balance of terrestrial ecosystems in China. Nature, 2009, 458 (7241): 1009-1013

9. Piao S, Ciais P, Huang Y, Shen Z, Peng S, Li J, Zhou L, Liu H, Ma Y, Ding Y, Friedlingstein P, Liu C, Tan K, Yu Y, Zhang T, Fang J. The impacts of climate change on water resources and agriculture in China. Nature, 2010, 467(7311): 43-51

10. Ju X T, Xing G X, Chen X P, Zhang S L, Zhang L J, Liu X J, Cui Z L, Yin B, Christie P, Zhu Z L, Zhang F S. Reducing environmental risk by improving $\mathrm{N}$ management in intensive Chinese agricultural systems. Proceedings of the National Academy of Sciences of the United States of America, 2009, 106(9): 3041-3046

11. Liu X, Zhang Y, Han W, Tang A, Shen J, Cui Z, Vitousek P, Erisman J W, Goulding K, Christie P, Fangmeier A, Zhang F. Enhanced nitrogen deposition over China. Nature, 2013, 494(7438): 459-462

12. Fu B J, Zhuang X L, Jiang G B, Shi J B, Lü Y H. Environmental problems and challenges in China. Environmental Science \& Technology, 2007, 41(22): 7597-7602

13. Zhang F, Cui Z, Zhang W. Managing nutrient for both food security and environmental sustainability in China: an experiment for the world. Frontiers Agricultural Science \& Engineering, 2014, 1(1): 53-61

14. Li Y, Zhang W, Ma L, Wu L, Shen J, Davies W J, Oenema O, Zhang F, Dou Z. An analysis of China's grain production: looking back and looking forward. Food and Energy Security, 2014, 3(1): 19-32

15. Liu G, Liu X, Cheng S. Food security: curb China's rising food wastage. Nature, 2013, 498(7453): 170

16. Cheng S K, Gao L W, Xu Z R, Tang C C, Wang L G, Dhruba B G C. Food waste in catering industry and its impacts on resources and environment in China. China Soft Science, 2012, 7: 106-114 (in Chinese)

17. Liu G. Food Losses and Food Waste in China. Trondheim: $O E C D$ Publishing, 2013

18. Liu J, Diamond J. China's environment in a globalizing world. Nature, 2005, 435(7046): 1179-1186

19. Zhai F, Wang H, Du S, He Y, Wang Z, Ge K, Popkin B M. Lifespan nutrition and changing socio-economic conditions in China. Asia

Pacific Journal of Clinical Nutrition, 2007, 16(Suppl 1): 374-382

20. Zhai F, Wang H, Du S, He Y, Wang Z, Ge K, Popkin B M. Prospective study on nutrition transition in China. Nutrition Reviews, 2009, 67(Suppl 1): S56-S61

21. FAO. FAOSTAT database. Available at FAO Website on January 23, 2013

22. Wang F, Dou Z, Ma L, Ma W, Sims J T, Zhang F. Nitrogen mass flow in China's animal production system and environmental 
implications. Journal of Environmental Quality, 2010, 39(5): 15371544

23. Lichtenberg E, Ding C G. Assessing farmland protection policy in China. Land Use Policy, 2008, 25(1): 59-68

24. WTO. Trade Policy Review-China. Geneva: WTO, 2012

25. Liu E K, He W Q, Yan C R. 'White revolution' to 'white pollution'agricultural plastic film mulch in China. Environmental Research Letters, 2014, 9(9): 091001

26. Huang J K, Wang X B, Zhi H Y, Huang Z R, Rozelle S. The effect on the grain production by the subsidy on grain production and the agricultural materials in China. Agrotechnical Economics, 2011, 1: 4-12 (in Chinese)

27. The state administration of grain in China (SAG). The implementation of the rural food postpartum detract security engineering. Beijing: SAG, 2009 (in Chinese)

28. The Central Government of the People's Republic of China. The notice of strengthening food saving and eliminating food waste. Beijing: The Central Government of the People's Republic of China, 2010

29. Xu S W. Analysis on food consumption and waste of China. Food and Nutrient in China, 2005, 11: 4-8 (in Chinese)

30. Wang J J, Deng Y X, Dou W, Yang Z L, Jiang T K. The major achievements of grain storage in P. R. China. Proceeding of the 10th International Working Conference on Stored Product Protection. Julius-Kühn-Archiv, 2010, 425: 50-60

31. Lan S B. Study on farm grain storage in China. 9th International Working Conference on Stored Product Protection. IWCPP Proceedings: 2009: 47-52

32. Ma H Y. Study on the change of eating in outside of home, demand for animal products and style of food consumption in China. Dissertation for the Doctoral Degree. Beijing: Chinese Academy of Agricultural Sciences, 2000 (in Chinese)

33. Wei J, Ma L, Lu G. The influence of urbanization on nitrogen flow and recycling utilization in food consumption system of China. Acta Ecologica Sinica, 2008, 28(3): 1016-1025 (in Chinese)

34. Dong X, Hu B. Regional difference in food consumption away from home of urban residents: a panel data analysis. Agriculture and Agricultural Science Procedia, 2010, 1: 271-277

35. Ma H, Huang J, Fuller F, Rozelle S. Getting rich and eating out: consumption of food away from home in urban China. Canadian Journal of Agricultural Economics, 2006, 54(1): 101-119

36. China General Chamber of Commerce. The Chinese national bureau of statistics-the retail and chain restaurant statistical yearbook. Beijing: China Statistics Press, 2011

37. Zhang D Q, Tan S K, Gersberg R M. Municipal solid waste management in China: status, problems and challenges. Journal of Environmental Management, 2010, 91(8): 1623-1633

38. Tai J, Zhang W, Che Y, Feng D. Municipal solid waste sourceseparated collection in China: a comparative analysis. Waste Management, 2011, 31(8): 1673-1682

39. Chen X, Geng Y, Fujita T. An overview of municipal solid waste management in China. Waste Management, 2010, 30(4): 716-724

40. Jiang J, Sui J, Wu S, Yang Y, Wang L. Prospects of anaerobic digestion technology in China. Tsinghua Science and Technology, 2007, 12(4): 435-440

41. Ma L, Velthof G L, Wang F, Qin W, Zhang W, Liu Z, Zhang Y, Wei J, Lesschen J P, Ma W, Oenema O, Zhang F. Nitrogen and phosphorus use efficiencies and losses in the food chain in China at regional scales in 1980 and 2005. Science of the Total Environment, 2012, 434: 51-61

42. Ma L, Ma W, Velthof G L, Wang F, Qin W, Zhang F, Oenema O. Modeling nutrient flows in the food chain of China. Journal of Environmental Quality, 2010, 39(4): 1279-1289

43. Ma L, Zhang W, Ma W, Velthof G L, Oenema O, Zhang F. An analysis of developments and challenges in nutrient management in china. Journal of Environmental Quality, 2013, 42(4): 951-961

44. Ma W, Li J, Ma L, Wang F, Sisák I, Cushman G, Zhang F. nitrogen flow and use efficiency in production and utilization of wheat, rice and maize in China. Agricultural Systems, 2008, 99(1): 53-63

45. UK-China Sustainable Agriculture Innovation Network (SAIN). Improved nutrient management in agriculture - a neglected opportunity for China's low carbon growth path. Beijing: SAIN, 2010

46. Chinese food waste is beyond imagination. Available at People Net Website in 2012

47. Lin T, Yu Y, Bai X, Feng L, Wang J. Greenhouse gas emissions accounting of urban residential consumption: a household survey based approach. PLoS ONE, 2013, 8(2): e55642

48. Liu J, Lundqvist J, Weinberg J, Gustafsson J. Food losses and waste in China and their implication for water and land. Environmental Science \& Technology, 2013, 47(18): 10137-10144

49. Liu J, Diamond J. Science and government: revolutionizing China's environmental protection. Science, 2008, 319(5859): 37-38

50. Katz D L. Agriculture: chewing on the food chain. Science, 2006, 314(5800): 762-763 